\title{
LACTONES OF Achillea millefolium
}

Achillea millefolium L. (common yarrow) has previously yielded acetylbalchanolide, millefolide, and a lactone with $\mathrm{mp} 138^{\circ} \mathrm{C} \mathrm{[1]}$, and also leucodin and achillin [2].

We have investigated the lactones of the leaves and flower heads of Achillea millefolium collected in the Bostandyk region of Tashkent oblast in the flowering stage (July, 1970). The air-dry raw material was extracted with ethanol, and the extract was concentrated and diluted $1 / 3$ with water. The aqueous ethanolic solution, after filtration, was shaken with chloroform, and the chloroform extract was chromatographed on neutral alumina. Elution with benzene and benzene-ether $(8: 2)$ gave three lactones. By a comparison of the IR spectra and a mixed melting point, one of them was identified as desacetylmatricarin [3], this being the first time that this substance has been found in this species of Achillea.

The IR spectrum of the second lactone $\left(\mathrm{mp} 188-189^{\circ} \mathrm{C}\right)$ showed absorption bands at $1790 \mathrm{~cm}^{-1}(\mathrm{C}=\mathrm{O}$ of a $\gamma$-lactone), 1745 and $1245 \mathrm{~cm}^{-1}$ (acetyl group), and $1690 \mathrm{~cm}^{-1}$ (conjugated carbonyl group). A comparison of this spectrum with the IR spectrum of matricarin shows that the structures of the two lactones are similar and, apparently, they are isomeric compounds.

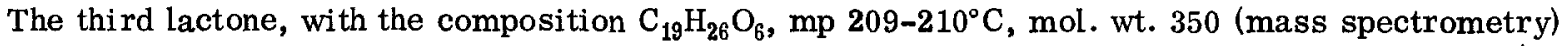
proved to be new, and we have named it millefin. Its IR spectum shows absorption bands at $1770 \mathrm{~cm}^{-1}$ $\left(\mathrm{C}=\mathrm{O}\right.$ of a $\gamma$-lactone), 1735 and $1250 \mathrm{~cm}^{-1}$ (acetyl groups), and $1670 \mathrm{~cm}^{-1}$ (double bonds). The NMR spectrum ( $\delta$ scale) has the following signals: doublet at $1.23 \mathrm{ppm}(\mathrm{J}=8 \mathrm{~Hz})\left(-\mathrm{CH}-\mathrm{CH}_{3}\right)$, and singlets at 1.45 and $1.65 \mathrm{ppm}$ due to methyl groups on double bonds. Singlets at 1.98 and $2.04 \mathrm{ppm}$ correspond to the protons of two acetyl groups, and a lactone proton is responsible for the signal at $4.70 \mathrm{ppm}$. Protons at $\mathrm{C}_{3}$ and $\mathrm{C}_{8}$ are represented by a multiplet at $5.09 \mathrm{ppm}$. By comparing the results obtained with the properties of acetylartabin [4], the following most probable structural formula may be proposed for millefin:

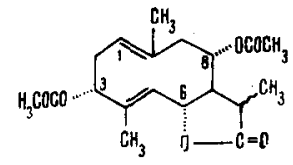

\section{LITERAT URE CITED}

1. J. Hochmannova, V. Herout, and F. Šorm, Collection Czech. Chem. Commun., 26, 1826 (1961).

2. R. de V. Alfonso and F. Olmos, Rev. Soc. Quim. Mex., 12, No. 5, 212A (1968).

3. K. S. Rybalko, A. I. Ban'kovskii, and R. I. Evstratova, Med. Prom. SSSR, 1962, No. 3, 13.

4. I. S. Akhmedov, Sh. Z. Kasymov, and G. P. Sidyakin, Khim. Prirodn. Soedin., 691 (1970).

Institute of the Chemistry of Plant Substances, Academy of Sciences of the Uzbek SSR. Translated from Khimiya Prirodnykh Soedinenii, No. 2, pp. 246-247, March-April, 1972. Original article submitted December 21, 1971.

- 1974 Consultants Bureau, a division of Plenum Publishing Corporation, 227 Thest 17th Street, Neu York, Y. Y. 10011. No part of this publication may be reproduced, stored in a retrieval system, or transmitted, in any form or by any means, electronic, mechanical, photocopying, microfilming, recording or otherwise, without written permission of the publisher. A copy of this article is available from the publisher for $\$ 15,00$. 